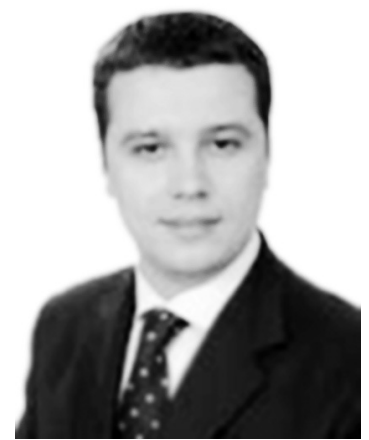

\title{
ПРОБЛЕМИ ІМПЛЕМЕНТАЦІї ПОЛОЖЕНЬ РИМСЬКОГО СТАТУТУ МІЖНАРОДНОГО КРИМІНАЛЬНОГО СУДУ ЩОДО ВОЕННИХ ЗЛОЧИНІВ У ЗАКОНОДАВСТВО ДЕРЖАВ-УЧАСНИЦЬ
}

\author{
ПИЛИПЕНКО Володимир Пилипович - кандидат юридичних наук, \\ Заслужений юрист України, член Европейської комісії «За демократію через \\ право» (2013-2017 pp.)
}

DOI:10.32782/EP.2020.2.3

В статье исследуются актуальнъие вопросъ имплементации положений Римского статута Международного уголовного суда относительно военных преступлений в законодательство некоторьхх государств-участников Римского статута. Обосновъгвается тезис о том, что подписание и ратификачия Римского статута накладъгвает на присоединившиеся государства обязательства привести свое национальное законодательство и правоприменительную практику в соответствии с положениями Статута. Так, в законодательстве государств-участнии должнь получить закрепление приниип комплиментарности юрисдикции Суда в отношении юрисдикции нацциональных судов и принцип недопустимости ссъллки на должностное положение лица для освобождения ее от ответственности. Констатируется, что параметрь восприятия положений Римского статута в контексте наказания за военнъие преступления определяются самим государством в его внутреннем законодательстве, с учетом типа ее правовой системъ, конституционных положений, а также международно-правовых обязательств государства.

Ключевъе слова: Римский статут Международного уголовного суда, Международнъий уголовньии суд, имплементация, трансформация, военнъле преступления, уголовное законодательство, принции комплиментарности и др.

Постановка проблеми

Міжнародне співтовариство давно прагнуло до створення постійно діючого міжнародного судового органу, покликаного притягати до відповідальності осіб, які винні в скоєнні найбільш тяжких злочинів, таких як геноцид, агресія, злочини проти людяності, воєнні злочини. Аюдству довелося пережити трагедії двох світових воєн, геноцид у Югославії і в Руанді, щоб прийти до усвідомленого і узгодженого рішення створити перший в історії постійно діючий Міжнародний кримінальний суд (далі - МКС, Суд). На Дипломатичній конференції повноважних представників, що проходила під егідою ООН в Римі, 17 липня 1998р. був прийнятий Статут Міжнародного кримінального суду [20] (далі - Статут MKC).

Основне завдання МКС полягає в здійсненні міжнародного правосуддя над особами, обвинувачуваними у скоєнні найтяжчих міжнародних злочинів. У преамбулі його Статуту підкреслюється, що Суд пов'язаний 3 системою ООН і має юрисдикцію щодо найбільш тяжких злочинів, що викликають занепокоєння всього міжнародного співтовариства. Приєднання держави до Статуту МКС тягне за собою істотні наслідки для іiі правової системи. 3 урахуванням того, що ратифікація Статуту МКС накладає на відповідні держави зобов'язання привести своє національне законодавство і правозастосовчу практику відповідно до положень Статуту, в законодавстві держав-учасниць мають отримати закріплення принцип компліментарності юрисдикції МКС по відношенню до юрис- 
дикції національних судів і принцип неприпустимості посилання на посадове становище особи для звільнення ії від відповідальності. Крім того, держава зобов'язана вжити заходів, що забезпечують взаємодію з МКС і гарантують передачу Суду осіб, обвинувачених у вчиненні злочинів, і участь у фінансуванні діяльності МКС.

Станом на 5 березня 2019 року 124 держави ратифікували або приєднались до Статуту МКС. Наразі законодавство щодо імплементації положень Статуту МКС прийняло близько 40 держав, у тому числі Австралія, Аргентина, Бельгія, Великобританія, Німеччина, Грузія, Іспанія, Канада, Литва, Мальта, Нідерланди, Нова Зеландія, Португалія, Уругвай, Фінляндія, Швейцарія, ПАР і низка інших країн. Ще кілька десятків держав, які ратифікували Статут МКС, знаходиться в процесі розробки і прийняття необхідних для імплементації актів [13, с. 76$]$.

Таким чином, метою цієї статті є дослідити особливості та проблемні питання в процесі імплементації положень Статуту Міжнародного кримінального суду в законодавство деяких зарубіжних держав-учасниць Статуту.

\section{Аналіз останніх публікацій і досліджень}

Питання створення, функціонування та імплементації положень Статуту МКС досліджувались такими вітчизняними вченими, як: В.Ф. Антипенко, В.А. Базов, М.В. Буроменський, В. Г. Буткевич, М.М. Гнатовський, Н.В. Дрьоміна, С.О. Загороднюк, Н.А. Зелінська, О.В. Касинюк, А.О. Кориневич, Г.А. Кохан, І.О. Колотуха, В.М. Аисик, А. С. Мацко, А.А. Маєвська, B.М. Репецький, В.П. Попович, М.I. Хавронюк, О.Р. Фісенко, В.Х. Ярмакі та ін.

Серед зарубіжних учених варто відзначити роботи, зокрема, Р.А. Адельханяна, М.ШІ. Басіоуні, І.П. Бліщенка, В.А. Вдовіна, I.I. Карпеця, А.Г. Кибальника, М.І. Костенка, М. Моріс, В.Н. Русинової, М.А. Саркисяна, Н.А. Сафарова, І.Г. Соломоненко, Є.Н. Трікоз, Б.Б. Ференца, I.В. Фісенко та ін.

\section{Виклад основного матеріалу}

Держави, як це випливає зі змісту відповідних норм чинного міжнародного права і підтверджується правозастосовчою практикою, несуть основні зобов'язання у зв'язку із забезпеченням кримінального переслідування і покарання осіб, які вчинили воєнні злочини. У зв'язку з цим, особливого значення набуває питання криміналізації в національному кримінальному законодавстві серйозних порушень норм міжнародного гуманітарного права (далі - МГП), що застосовується в збройних конфліктах. Міжнародно-правові акти, що діють в даній сфері, покладають на держав-учасниць зобов'язання криміналізувати такого роду серйозні порушення МГП і передбачити їх кримінальну відповідальність, беручи до уваги їх міжнародну та суспільну небезпеку.

Як зазначає С.А. Аобанов, «у цілому йдеться про два взаємопов'язані фактори, що лежать в основі даного процесу. Поперше, слід враховувати вплив міжнародного права, що володіє пріоритетом у питанні криміналізації такого роду діянь (як злочинів проти миру і безпеки людства). У спеціальній літературі [1, с. 175-176] обгрунтовано зазначається, що норми внутрішньодержавного права не можуть суперечити міжнародному праву, більше того, повинні забезпечувати реалізацію вимог міжнародно-правових норм, обов'язкових для даної держави ${ }^{1}$. I у цьому зв'язку підхід до криміналізації аналізованих діянь і заходів покарання за них повинен відповідати вимогам міжнародного кримінального права. По-друге, параметри сприйняття положень міжнародного кримінального права визначаються самою державою, 3 урахуванням типу іiї правової системи, кон-

\footnotetext{
1 Таке розуміння повною мірою узгоджується 3 нормами чинного міжнародного права. Зокрема, в ст. 27 Віденської конвенції про право міжнародних договорів від 23 травня 1963 р. закріплено положення, згідно з яким держава - учасниця договору не може посилатися на положення свого внутрішнього права як на виправдання невиконання нею договору. 3 проблеми виконання міжнародних договорів в контексті принципу добросовісності./ Див., наприклад: [9, с. 168-210] .
} 


\section{Теорія, історія держави і права, конституційне право}

ституційних положень, що діють у ній, а також їі міжнародно-правових зобов'язань, у зв’язку з участю в міжнародних договорах» [12, с. 267].

Причому, тут слід враховувати не тільки специфіку континентальних правових традицій і традицій загального права, а й національно-правові особливості, регіональний фактор. Так, можна вести мову про певну подібність кримінально-правових систем держав СНД, а також і інших інтеграційних об'єднань, що, звичайно, не виключає відмінностей, іноді досить істотних, у підході до криміналізації воєнних злочинів у кримінальному законодавстві держав. Не випадково МКЧХ у ході роботи щодо організації і координації дій держав у рамках виконання ними зобов'язань щодо імплементації МГП (яке, як підкрес^юється МКЧХ, у цілому повинно бути універсальним, оскільки його метою $є$ захист жертв збройних конфліктів) запропонував розробляти, поряд 3 іншими документами, типові закони, що орієнтовані на прийняття імплементаційних заходів, з урахуванням регіональних рамок або подібності правових систем відповідних груп держав $[5$, c. 83].

Що стосується конкретного способу виконання цього зобов'язання, техніки законодавчого опису діянь, що криміналізуються, заходів і видів покарань, то тут держава має вибір. Зарубіжні вчені, досліджуючи проблеми національно-правової імплементації у зв'язку з участю держав у Статуті МКС, відзначають, що фактично національні системи зберігають автономію свого кримінального права навіть після вступу Статуту МКС у силу для них, оскільки нормативний стандарт, передбачений Статутом , полягає в бажанні і здатності держави здійснювати кримінальне переслідування (ст. 17 Статуту МКС), і у зв'язку з цим деяка відмінність формулювань складів злочинів у національному праві від відповідних визначень, що містяться в Статуті МКС, самі по собі не можуть бути перешкодами для здійснення державою кримінального переслідування [2, с. 161].

Кримінальний закон держави може містити вказівку на можливість прямого від- силання до норми міжнародного права при вирішенні кримінально-правових питань, у тому числі у зв'язку з криміналізацією воєнних злочинів. Крім того, приведення норм національного кримінального закону в питаннях злочинності і караності діяння у відповідність до вимог міжнародного права за загальним правилом здійснюеться за допомогою сприйняття нормами національно-правової системи приписів системи міжнародно-правової. У свою чергу, як зазначається в літературі, таке сприйняття може бути проведено трьома шляхами:

1) текстуального включення норми міжнародного кримінального права в кримінальне законодавство на виконання міжнародного договору;

2) включення норми міжнародного кримінального права в кримінальне законодавство, причому припис міжнародного договору не встановлюе жорсткої форми сприйняття його приписів у внутрішньодержавному праві;

3) зміни вже наявних норм кримінального законодавства на виконання положень міжнародного кримінального права [11, c. 187-188].

Крім того, $з$ певною часткою узагальнення, можна вести мову про наступні два (поряд з прямим відсиланням) основні способи впливу міжнародного права на національне кримінальне законодавство: рецепція - акт міжнародного права як джерело кримінального права повністю включається в кримінальний закон без будь-яких змін, при цьому може вводитися нова норма або змінюватися сучасна; імплементація - вже наявна кримінально-правова норма або (частіше) вводиться нова норма кримінального закону, що адаптується внутрішнім законодавцем на виконання міжнародного договору [10, с. 192-193].

Як показує практика, держави використовують вищезгадані варіанти, при цьому нерідко їх поєднують.

Насамперед слід відзначити, що вітчизняна юридична література неоднозначно називає процес узгодження норм внутрішньодержавного і міжнародного права. Найбільш часто пропонуються наступні терміни: «рецепція», «трансформація», «націо- 
нально-правова імплементація» або просто «імплементація», «здійснення» (реалізація), «застосування», «виконання». Майже всі автори розуміють під цими найменуваннями механізм здійснення (реалізації) норм міжнародного права. У міжнародному праві для позначення поняття «здійснення» норм міжнародного права широкого поширення набув термін «імплементація норм міжнародного права».

у Словнику міжнародно-правових термінів термін «імплементація» (від лат. implere - наповнювати, досягати, виконувати, здійснювати) в міжнародному праві розуміється як організаційно-правова діяльність держав з метою реалізації своїх міжнародно-правових зобов'язань [4, с. 184]. Термін «імплементація» буквально означає «втілення в життя відповідно до певної процедури» [27, р. 667], «забезпечення практичного результату і фактичного виконання конкретними засобами» [36, р. 1134].У свою чергу, «імплементація (міжнародного права) - фактична реалізація міжнародних зобов'язань на внутрішньодержавному рівні, яка здійснюється шляхом трансформації міжнародно-правових норм у національні закони та підзаконні акти»[25, с. 116$]$.

Цей термін набув широкого поширення в численних резолюціях Генеральної Асамблеї ООН і ї̈ органів, у багатьох міжнародних конвенціях та інших міжнародно-правових актах. Значного поширення у міжнародно-правовій літературі набули також вирази «механізм імплементації», «імплементаційні статті». При цьому під механізмом імплементації розуміють передбачену міжнародним договором систему заходів контролю за його виконанням або певні органи, створені з цією метою міжнародним договором, та процедура їх роботи. Поняття «імплементаційні статті» означає ті статті договору, що передбачають систему заходів для реалізації договору.

У довідковій літературі можна зустріти такі визначення цього терміна: «імплементація - в широкому сенсі слова означає здійснення міжнародно-правових і внутрішньодержавних норм на виконання міжнародно-правових, а також створення на міжнародному та внутрішньодержавному рівнях умов для такого здійснення» [21, c. 102].

О. Скакун вважає, що імплементація «це перенесення (введення) у національне право норм і принципів міжнародних актів» [19, с. 63]. Професор В.А. Чубарєв під імплементацією розуміє «запровадження норм міжнародно-правового договору у національне законодавство» [24, с. 250]. М.Ю. Черкес зазначає, що «трансформація - це введення норми міжнародного права у внутрішньодержавну правову систему в результаті здійснення певних процесуальних дій. Інакше цю процедуру ще іменують імплементацією норм міжнародного права, хоча імплементацію слід розуміти ще у широкому значенні як процедуру реалізації норм міжнародного права у внутрішньодержавному праві» [14, с. 34]. На думку А. Дмітрієва та В. Муравйова, «реалізація (імплементація) норм міжнародного права - це процес, коли відповідні суб'єкти, яким адресована міжнародно-правова норма, діють згідно з її положеннями» [15, с. 184].

Професор А.С. Гавердовський зазначає, що «в міжнародному праві для забезпечення поняття «здійснення» норм міжнародного права широке поширення набув термін «імплементація» [3, с. 49]. А.С. Гавердовський розуміє під імплементацією цілеспрямовану організаційно-правову діяльність держав, що здійснюється індивідуально, колективно або в рамках міжнародних організацій 3 метою своєчасної, всебічної та повної реалізації прийнятих ними відповідно до міжнародного права зобов'язань [3, с. 62].-

Це визначення видається найбільш повним, оскільки його очевидна перевага полягає в тому, що тут зафіксовано підхід до процесу реалізації міжнародного права як до органічного поєднання правотворчої i організаційної діяльності держав, що здійснюється ними всередині держави і на міжнародній арені, в тому числі за допомогою і в рамках сучасних або знову створюваних інституційних структур. Згідно 3 цим визначенням імплементація є підготовча стадія реалізації, необхідна для забезпечення своєчасної, всебічної та повної реалізації 


\section{Теорія, історія держави і права, конституційне право}

норм, тобто вона, по суті, ототожнюеться із забезпеченням реалізації.

Отже, про імплементацію міжнародноправових норм можна говорити тільки в тому випадку, якщо держава не тільки видає відповідні законодавчі акти (змінює чи скасовує вже наявні) для здійснення норм міжнародного права, а й проводить в життя ці акти. Тому національно-правова імплементація норм міжнародного права - це тільки етап у процесі їх імплементації (здійснення), вона створює лише юридичні передумови для їх виконання. Імплементація норм міжнародного права - результат також фактичних дій.

Отже, найпоширенішими способами імплементації міжнародно-правових норм у національну систему права є: 1) рецепція, тобто текстуальне повторення нормотворчим органом держави змісту міжнародноправової норми в статті нормативно-правового акта; 2) трансформація, під якою розуміється переробка тексту міжнародно-правового акта чи окремих його статей із прийняттям на цій основі норм внутрішнього права; 3) відсилання, яке є вказівкою у внутрішньодержавному нормативно-правовому акті на міжнародне право як на джерело, що регулює ці відсильні відносини.

Національну систему імплементації становлять органи державної влади й інші органи держави, уповноважені забезпечувати виконання державою міжнародно-правових зобов'язань. Оскільки норми міжнародного права породжують правовідносини між суб'єктами міжнародного права і не породжують їх між суб'єктами внутрішнього права, необхідні додаткові внутрішньодержавні засоби для перетворення цілей, закладених у нормах міжнародного права, на реальні дії органів державної влади, юридичних осіб і громадян, які перебувають під юрисдикцією держави» [26, с. 667 668].

Як зазначається в міжнародно-правовій літературі, при вирішенні питання про відповідність Статуту МКС Конституції та іншим законодавчим актам необхідно виходити $з$ того, що він - не відірвана від сучасних правових реалій інституція, а ії частина, яку необхідно тлумачити з урахуван- ням положень міжнародного кримінального права, що розвивається. Традиційна концепція щодо участі чи неучасті держав у міжнародних угодах на основі їх суверенних прав не застосована до Римського статуту, оскільки його цілі та об'єкт регулювання склалися під впливом імперативних норм сучасного міжнародного права (jus cogens) [23, c. 123].

Як слушно зазначає О. Харитонова, «держава не може відмовити у застосуванні норми міжнародного права, посилаючись на особливості свого правопорядку, оскільки норми міжнародного права є продуктом міжнародного співробітництва. Міжнародний кримінальний суд виступає сильним публічним інститутом, відносини з яким у держав-учасників Римського статуту складаються за моделлю вертикального характеру: приймаються спеціальні закони про співробітництво і компетентний національний орган, про визнання імунітетів персоналу МКС, про порядок затримання і передачу осіб під юрисдикцію МКС, про порядок виконання доручень МКС і призначених ним покарань. Така «вертикальна» модель викликає побоювання у противників ратифікації Римського статуту, які висловлюють застереження, що самостійна правосуб'єктність МКС створюе загрозу національному суверенітету і навіть системі колективної безпеки ООН. Вбачається, тут варто підкреслити, що МКС заснований на підставі міжнародного договору, підконтрольний Асамблеї держав-учасниць, здійснює юрисдикцію на основі принципу компліментарності, має незалежного Прокурора, заснований на жорсткому професійному відборі суддів, фінансується всіма державами-учасниками. Необхідно пам'ятати, що Римський статут утворює загальну для всіх держав-учасників модель криміналізації міжнародних діянь, уніфікуючи відповідні частини національних кримінально-правових систем. Але оскільки закріплений у Статуті перелік міжнародних злочинів не вичерпний, країни в ході його імплементації можуть включати в законодавство додатково склади злочинів з урахуванням актів міжнародного гуманітарного права. Правова база співробітництва 
держав з МКС повинна базуватися на вирішенні таких основних питань: подоланні протиріч між конституційними нормами та Римським статутом; приведенні у відповідність національного кримінального законодавства; створенні правової підстави для ефективного співробітництва з МКС 3 урахуванням специфіки його процедур [23, c. 123].

У світлі зазначеного, як слушно зазначає О. Харитонова, «виникає питання про те, як держава зі своїм механізмом реалізує положення міжнародних кримінальноправових норм, оскільки міжнародне право проникає всередину державної правової матерії і захоплює сферу внутрішньоправового регулювання. Перспективними в галузевих правових дослідженнях є питання про те, як співвідносити дану галузь права 3 тими правовими новелами, обов'язками, які виникли у держави на рівні міжнародного спілкування; наскільки чітко на доктринальному та практичному рівнях вибудовано концепцію співвідношення міжнародного та національного кримінального права; яким чином встановлюються принципи і обсяг правового регулювання в цій сфері; які принципи криміналізації та кримінального переслідування тут встановлені і яким є санаційне забезпечення такого переслідування» [23, с. 123].

Так, у Посібнику для ратифікації та імплементації Римського Статуту [17] вказується, що достатніми для приведення законодавства країни у відповідність до положень Статуту МКС є такі заходи: 1) прийняття визначення, яке повністю відтворює текст відповідної статті Статуту чи містить пряме відсилання до нього; 2) передбачити окремі склади злочинів для кожного 3 діянь, згаданих у Статуті. Можливо певною мірою змінити визначення відповідного злочину, але зі збереженням аналогічного зі Статутом змісту або ж з його розширенням, щоб гарантовано не давати можливості винним уникнути відповідальності; 3) держави можуть притягувати до кримінальної відповідальності на основі загальнокримінальних складів злочинів. Одним із способів тут називається застосування наявних у національному законодавстві складів злочинів, подібних за змістом, якщо не за формою, до складів злочинів, закріплених у Статуті. Держави можуть переслідувати за діяння, яке прирівнюється до визначених у Статуті злочинів, використовуючи достатньо серйозні національні склади злочинів, що давало 6 підстави для тверджень, що відповідний злочин вчинено (такий підхід характерний для Данії та Норвегіï) [17].

3 одного боку, така можливість передбачається у вказаному вище Посібнику, проте тут зазначається і те, що справа підпадатиме під провадження МКС, зокрема, якщо національні принципи індивідуальної кримінальної відповідальності, підстави для виключення кримінальної відповідальності або застосовувані покарання суттево відрізняються від передбачених Статутом. Останнє положення, на нашу думку, автоматично виключає застосування державами складів загально кримінальних злочинів як підстави для притягнення до відповідальності осіб за діяння, що утворюють склади злочинів, закріплені у Статуті [17]. В іншому документі зазначається, що національний закон, у якому криміналізовано певне діяння, навряд чи буде достатнім для цілей включення злочинів, відповідальність за які передбачена у Статуті, у національний закон. Такий звичайний злочин, як вбивство не є однаковим зі злочином проти людяності чи воєнним злочином, що вчинені шляхом вбивства, оскільки відсутня необхідна мета, через що перший не проходить межового критерію міжнародних злочинів [17].

Деякі держави, такі як СІІА, Великобританія, Канада, Нідерланди, Швеція і Швейцарія, застосовують імплементуюче законодавство, передбачаючи злочин у національному праві. Окремі покладаються на пряму застосовність міжнародного права у національній системі права. Інші ж лише застосовують аналогічні національні злочини.

Крім того, зауважимо, що при визначенні конкретних способів, якими держава може скористатися для приведення національного законодавства у відповідність до Статуту МКС, вкрай важливим і корисним є ознайомлення з положеннями деяких між- 


\section{Теорія, історія держави і права, конституційне право}

народних документів, розроблених міжнародними організаціями 3 метою сприяти приєднанню та пришвидшити процес узгодження національних законів держав зі Статутом МКС. До таких, зокрема, належать: Керівні Принципи для ефективної імплементації Римського Статуту [28]; Контрольний список для імплементації Римського Статуту [32]; Нездатність держав ефективно імплементувати Римський Статут [30]; 14 принципів для ефективного здійснення універсальної юрисдикції [33]; Універсальна юрисдикція: обов'язок держав встановити та імплементувати законодавство [34]; Посібник для імплементації та ратифікації [17]; Парламентський Пакет документів з Міжнародного Кримінального Суду [16]; Керівництво 3 імплементації та ратифікації Римського Статуту[29]; Довідник 3 імплементації Римського Статуту [31].

Одним 3 найбільш важливих елементів виконання зобов'язань за МГП на національному рівні є впровадження в дію комплексної правової системи для ефективного судового переслідування і покарання осіб, які вчинили серйозні порушення МГП. Майже всі договори у сфері міжнародного кримінального права та МГП вимагають, щоб були створені можливості для судового переслідування осіб, які вчинили будь-які серйозні порушення їх положень, для чого необхідно, як правило, прийняти відповідне законодавство.

Отже, проаналізуємо законодавство деяких держав-учасниць Статуту МКС у контексті закріплення складів воєнних злочинів у національному законодавстві. Видається, що у цьому сенсі найбільш цікавим є досвід тих зарубіжних держав, які безпосередньо зіткнулися з вчиненням воєнних злочинів їх громадянами і (або) на їх територіях.

Очевидно, найяскравішим прикладом розвитку національного законодавства щодо воєнних злочинів на основі міжнародного кримінального права 6 прийняття в ФРН Кодексу міжнародного кримінального права (далі - Кодекс ФРН), введеного в дію 26 червня 2002 року («Volkerstrafgesetzbuch» - VStGB)[35]. Кодекс ФРН складається з За- гальної та Особливої частин. У Загальній частині закріплюється принцип універсальної юрисдикції, закріплено особливу обставину, що виключає винність, це наказ або розпорядження, встановлюються норми щодо командної відповідальності і незастосування строків давності. Особлива частина кодексу встановлює відповідальність за геноцид (ст. 6), злочини проти людяності (ст. 7), воєнні злочини (ст. 8-12) i інші, пов'язані з міжнародними злочини(ст. 13-14). У ст. 8 Кодексу закріплена відповідальність за воєнні злочини щодо фізичних осіб. Ст. 9 Кодексу ФРН впроваджує кримінальну відповідальність за воєнні злочини проти власності та інших прав. Крім того, ст. 10 даного акту встановлює кримінальну відповідальність за воєнні злочини проти гуманітарних операцій i за незаконне використання розпізнавальних емблем Женевських конвенцій, ООН та інших, якщо це спричинило заподіяння смерті або шкоди здоров'ю людини.

Статті 11 і 12 Кодексу ФРН регламентують відповідальність за воєнні злочини, що пов'язані із використанням заборонених міжнародним правом засобів і методів ведення воєнних дій. Стаття 12 Кодексу ФРН прямо перераховує деякі з видів забороненої зброї, застосування яких тягне за собою кримінальну відповідальність. Слід зазначити, що після довгого періоду відсутності практики застосування Кодексу Вищий земельний суд у Штутгарті 28 вересня 2015 року на підставі Кодексу міжнародного кримінального права ФРН 2002 р. засудив двох лідерів Демократичних сил звільнення Руанди Ігнаса Мурваначьяку і Стратона Мусона до реальних термінів позбавлення волі за керівництво терористичною організацією і сприяння у вчиненні воєнних злочинів [6].

Іншим прикладом приведення національного законодавства щодо воєнних злочинів у відповідність 3 міжнародним кримінальним правом є Хорватія, на території якої мало місце кілька збройних конфліктів, у тому числі міжнародного характеру. Розвиток національного законодавства про воєнні злочини в цьому випадку був пов'язаний з трьома факторами [8, с. 199]: 
по-перше, Хорватія прагнула вступити до GC; по-друге, в національні суди Хорватії надійшла низка справ від Міжнародного трибуналу по колишній Югославії на підставі правила 11-bis його Правил процедур і доказування [18] (чого 6, очевидно, не відбулося в разі невідповідності національного законодавства вимогам сучасного міжнародного кримінального права); по-трете, Хорватія ратифікувала Статут МКС, ухваливши Закон про ратифікацію Римського статуту.

У Кримінальному кодексі Республіки Хорватія [22] закріплений значний перелік воєнних злочинів проти цивільних осіб, що здійснюються під час війни, збройного конфлікту або окупації (ст. 158-168). Крім того, КК Хорватії як самостійний склад злочину розглядає «організацію групи або підбурювання до геноциду або воєнним злочинам» (ст. 123), «планування злочинів проти цінностей, що знаходяться під захистом міжнародного права» (ст. 187a), а також «наступну допомогу особі, яка вчинила злочин проти цінностей, що знаходяться під захистом міжнародного права» (ст. 187b).

Положення КК Хорватії про воєнні злочини активно застосовуються на практиці. Справи про військові злочини в Республіці Хорватія в першій інстанції розглядаються тільки окружними судами, які розташовані в Загребі, Спліті, Рієці, Осієку. Наразі в різних судах на стадії розгляду знаходиться 18 кримінальних справ про воєнні злочини [7].

Таким чином, з урахування наведеного вище аналізу законодавства Німеччини i Хорватії,можна дійти висновку, що ці держави демонструють нам два технічно різні способи зміни національного законодавства про воєнні злочини з метою виконання взятих на себе міжнародних зобов'язань. Звісно ж, даний досвід може бути дуже корисним при усуненні недоліків норм щодо воєнних злочинів у вітчизняному кримінальному законодавстві.

\section{Висновки та пропозиції}

Отже, кожна держава-учасниця Статуту МКС є вільною у виборі шляхів імплементації своїх договірних зобов'язань до тих пір, поки вона діє добросовісно і результат цих дій свідчить про здатність виконати всі зобов'язання за Статутом МКС. Під час імплементації Статуту МКС державам-учасницям доводиться вирішувати три основні блоки питань: 1) усунення суперечностей між Статутом МКС і конституційними актами держави; 2) приведення національного кримінального законодавства у відповідність до вимог Статуту МКС; 3) створення правової бази взаємодії з МКС. Як показує вже наявна практика імплементації, кожне із зазначених вище завдань може вирішуватися різними шляхами, виходячи з правових традицій конкретної країни або навіть простого розсуду законодавця.

Як було показано вище, в міжнародній практиці є різні моделі імплементації Статуту МКС в національних законодавствах, проте не можна сказати, що в Україні 6 можливість вибрати будь-яку з них. Суворі принципи нашої правової системи часом залишають єдиний шлях виконання імплементаційних процедур. Зокрема, принцип повної кодифікації кримінального законодавства вимагає, щоб зміни кримінально-правового характеру були включені до тексту Кримінального кодексу України, при цьому міжнародно-правові норми слід трансформувати відповідно до традиційвітчизняної юридичної техніки.

\section{Мітература}

1. Адельханян Р.А. Военные преступления в современном праве. М., 2006.

2. Верле Г. Принципи міжнародного кримінального права: підручник. М., 2011.

3. Гавердовский А.С. Имплементация норм международного права. К.: Вища школа, 1980.

4. Грін О.О. Словник міжнародно-правових термінів /Укладач О.О.Грін. Ужгород: ПП ДанилоС.I., 2010. 500 с.

5. Документ С.I/4.1/1 булопідготовлено МКЧХ для XXVI Міжнародної конференції Червоного Хреста і Червоного Півмісяця і представлений Раді делегатів Міжнародного руху Червоного Хреста і Червоного (2830 листопада 1991 р.) /Див.: Белый И.Ю. Международное уголовное судопроизводство. М., 2007. 


\section{Теорія, історія держави і права, конституційне право}

6. Ежегодный доклад Amnesty International о правах человека в современном мире. 2015-2016 гг. URL: http:// amnesty.org.ru/pdf/Annualreportbook15_16_ Russian.pdf

7. За даними хорватської неурядової правозахисної організації Documenta, основною метою якої є моніторинг судових процесів над військовими злочинцями. URL: https://www.documenta.hr/hr/su\%C4 \%9lenja-u-tijeku.

8. Йосипович И. Ответственность за военные преступления перед национальными судами в Хорватии. Международнъий журнал Красного креста. 2006. № 861.

9. Каламкарян Р.A. Право международных договоров. Применение международных договоров во времени и пространстве. М., 2015.

10. Кибальник А.Г. Введение в международное уголовное право. Ставрополь, 2001.

11. Кибальник А.Г. Современное международное уголовное право: понятие, задачи и принципы /Под науч. ред. А.В. Наумова. СПб., 2003.

12. Лобанов С.А. Международная уголовная ответственность за военные преступления. Дис. доктора юрид. наук. М., 2018. 495 с. URL: https://www.dissercat. com/content/mezhdunarodnaya-ugolovnayaotvetstvennost-za-voennye-prestupleniya

13. Международный уголовный суд: проблемы, дискуссии, поиск решений / Под ред. Г. И. Богуша, Е. Н. Т рикоз. М.: Европейская Комиссия, 2008. 792 с.

14. Міжнародне право. Підручник /Під ред. М.Ю. Черкеса. К.: Знання, 2000.

15. Міжнародне публічне право. Підручник. /Під ред. А. Дмітрієва, В. Муравйова. К.: Юрінком Інтер, 2000.

16. Нью-Йорская Декларация о парламентском действии в поддержку МУС от 12 сентября 2003 года URL: http://www. pgaction.org; http://www.victimstrustfund. org (Парламентский Пакет документов по Международному Уголовному Суду / [Парламентарии за Глобальное Действие]. http:// www.pgaction.org/uploadedfiles/FINAL\%20 KIT(12).pdf)

17. Пособие по ратификации и имплементации Римского Статута URL: http:// www.icclr.law.ubc.ca; info/12/muprirstatuta024.htm

18. Правила процедуры и доказывания МТБЮ (Rev. 37, 16 Nov. 2005) URL: http:// www.icty.org/x/file/Legal\%20Library/Rules procedure_evidence/IT032_rev37_en.pdf

19. Проблеми гармонізації законодавства України з міжнародним правом. Матер. наук.-практ. конференції (жовтень, 1998 року). К., 1998.

20. Римський статут міжнародного кримінального суду від 17.07.1998. URL: https://zakon.rada.gov.ua/laws/show/995_588

21. Словарь международного права. М., 1986.

22. Уголовный кодекс Республики Хорватия: URL: http://www.wipo.int/wipolex/ru/ text.jsp?file_id $=301780$

23. Харитонова О. Римський статут i Міжнародний кримінальний суд в контексті сучасних світових та українських кримінально-правових наукових тенденцій. Українсъкий часопис міжнародного права. №4/2014. С. 122-124.

24. Чубарев В.ภ. Парламентський контроль: практика України та міжнародний досвід. Проблеми державно-правової реформи в Україні. Зб. наук. праць. Вип. 3. К., 1997.

25. Юридический энциклопедический словарь. М.: ИНФРА-М, 1996.

26. Юридична енциклопедія: В 6 т. / Редкол.: Ю.С. Шемшученко (голова редкол.) та ін. - К.: «Укр. енцикл.». 1998. Т. 2: Д-Й. 1999.

27. Dictionary of Languag, N. Y., 1968.

28. International Criminal Court: Guidelines for effective implementation of the Rome Statute [Amnesty International] (AI Index: IOR 40/013/2004). September 1, 2004. URL: http://web.amnesty.org/library/print/ENGIOR400132004

29. International Criminal Court: Manual for the Ratification and Implementation of the Rome Statute. / [The International Centre for Criminal Law Reform and Criminal Justice Policy]. Third Edition. - Vancouver, March 2008. 120 p.

30. International Criminal Court: The failure of states to enact effective implementing legislation/ [International Amnesty] (IOR 40/019/2004). September1, 


\section{АНОТАЦІЯ}

у статті досліджуються актуальні питання імплементацї положень Римського статуту Міжнародного кримінального суду щодо воєнних злочинів у законодавство деяких держав-учаснищь Римсъкого статуту. Доводиться теза про те, шоо підписання і ратибікачія Римсъкого статуту накладає на держави, що приєдналися, зобов'язання привести своє національне законодавство $і$ правозастосовну практику відповідно до положень Статуту. Так, у законодавстві держави-учасниці повинні отримати закріплення принципу компліментарності юрисдикцій Суду по відношенню до юрисдикиї національних судів $i$ принииуу неприпустимості посилання на посадове становище особи для звільнення ї від відповідальності. Констатується, що параметри сприйняття положень Римсъкого статуту в контексті покарання за воєнні злочини визначаються самою державою у $і ̈$ внутрішнъому законодавстві, з урахуванням типу ї правової системи, конституиійних положень, а також міжнародно-правових зобов'язань держави.

Ключові слова: Римсъкий статут Міжнародного кримінального суду, Міжнародний кримінальний суд, імплементачія, трансбормачія, воєнні злочини, кримінальне законодавство, приници компліментарності ma iн.

2004. (Or: The failure of states to implement the Rome Statute effectively (AI Index: IOR 40\015\2004). - August, 2004) URL: http://web.amnesty.org/library/Index/ ENGIOR400192004?open\&of=ENG-385

31. Making the International Criminal Court work: A Handbook for Implementing the Rome Statute / [Human Rights Watch]. September 2001. Vol. 13, No. 4 (G). 32 p.

32. The International Criminal Court: Summary Checklist for Effective Implementation/ [Amnesty International] URL: http://web. amnesty.org/en/library/info/IOR40/015/2000/ en
33. Universal Jurisdiction: 14 Principles for the effective exercise of universal jurisdiction / [Amnesty International] (AI Index: IOR 53\001\99). May 1999. URL: http://www.amnesty.org/en/library/info/IOR53/001/1999

34. Universal Jurisdiction: The duty of states to enact and implement legislation [Amnesty International] (AI Index: IOR 53\002018\2001). September, 2001. URL: http:// www.amnesty.org

35. Volkerstrafgesetzbuch (VStGB). In der Fassung vom 26. Juni 2002. Fundstelle. BGB. 2002. N 1.

36. Westers Third New International Dictionary, Cambr. (Mass.), 1966.

\section{THE PROBLEMS OF IMPLEMENTATION OF THE INTERNATIONAL GRIMINAL COURT STATUTE PROVISIONS ON WAR CRIMES TO THE LEGISLATION OF THE STATES PARTIES TO THE ROME STATUTE}

Current issues of implementation of the International Criminal Court Statute provisions on war crimes in the legislation of some member states of the Rome Statute are examined in the article. It is argued that the signing and ratification of the Rome Statute imposes an obligation on the acceding states to bring their national legislation and law enforcement practices into line with the provisions of the Statute. Thus, member-states shell enshrine in law the principle of complementarity of the Court jurisdiction in relation to the jurisdiction of national courts and the principle of the inadmissibility of a reference to a person's official position in order to release him or her from liability. It is stated that the parameters of perception of the Rome Statute provisions on punishments for war crimes are determined by the state itself in its domestic legislation, taking into account the type of its legal system, constitutional provisions and international legal obligations of the state.

Keywords: Rome Statute, Statute of the International Criminal Court, International Criminal Court, implementation, transformation, war crimes, criminal law, principle of complementarity, etc. 